Kocziszky György, Doctor of Economics, Professor, Director of the Institute of Regional Economics, University of Miskolc (Miskolc, Hungary);

Veresné Somosi Mariann,

Doctor of Economics, Professor, Dean of the Department of Economics, University of Miskolc (Miskolc, Hungary)

\title{
SUPPORTING THE CREATION AND INSTALLATION OF REGIONAL SOCIAL INNOVATIONS WITH KNOWLEDGE ENGINEERING SYSTEM
}

The authors of the study allow us to conclude that the traditional focus of innovation (banking, manufacturing, management reform, etc.) not always with the same efficiency are perceived in various regions of the country. In some regions, these innovations do not lead to social improvement, which is a prerequisite necessary for the generation and implementation of separate unit for social innovation. The article substantiates the necessity of social innovation. For example, the functioning of the Centre for social innovation city of Miskolc for the first time developed a scientific and methodical approach to their implementation. As the main structural blocks of this approach, the authors offered the following: a) definition of the relationship of local economic development and social innovation; b) formation of key areas of the social improvements of the region (employment, added value, improved health and social conditions, improvement of infrastructure, development of the settlement); c) the development of social innovation on the basis of regional system engineering knowledge; g) selection of key social innovation based on the innovation matrix, and special techniques; d) develop programs for the practical implementation of innovation social orientation. Research and guidelines proposed in the article, were tested by the authors over the last two years. As a result a General conclusion that the biggest obstacle to social innovation is not lack of resources but lack of ideas and desires from a local and Central managerial elite.

Keywords: innovation activity, region, social innovation, innovation potential, knowledge creation, innovation matrix.

DOI: $10.21272 / \mathrm{mmi} .2017 .1-11$

Problem statement. Studies show that different regions of any country develop in different ways. They differ in the level of employment, wages, value added, the level of expenditures on research, infrastructural support, etc. typically, the regions that are closer to the capital, to the Central government have the best social indicators, while peripheral regions are the worst. Therefore, there arises a problem of a particular alignment of social indicators across regions of the country, creation tank for social innovation, the implementation of which will contribute to this task.

Analysis of recent research and publications. The innovation is an important influencing factor which determines the development of cen- tre-periphery relations. According to several empirical analyses, the economic output of the settlements and regions with outstanding innovation potential is also significantly higher in the converging countries than that of the territories with the lack of innovation [1-20]. While the R\&D\&I input, output and result indicators of the centres are much higher than the national average, the peripheries have values much be- low the national average. It has also got a dependent role on the fact that the European Union has supervised its innovation policy in the last two decades [5-8]. As a result of this, the support of social innovation became more important, which can foster the convergence mainly in the case of the peripheries $[15 ; 17 ; 19]$.

Unsettled components of the general problem. Among the studied works, it should be noted that insufficient attention is paid to the methods of selecting the best alternatives for the implementation of social innovation. That's why the authors define the problem in this article.

The aim of the article is identification of essence and features of application of social innovation in the current economic conditions of the Republic of Hungary. In order to realize this goal, it is necessary 
to solve the following problem: find the essence of social innovation, to develop a methodology of its creation and to determine the algorithm for its implementation.

The main material of the research. The formers/actors of economic policy often criticise the work of experts dealing with social innovation (sometimes rightly) that although the analyses with different frequency and time period are very useful, they do not answer the "how more?" question. The number of recommendations is relatively low, which can change on a sustainably way on the living and existential conditions of the inhabitants of settlements in peripheral regions.

Since the geopolitical changes of 1989 the regional level of social and economic disparities has increased in Hungary. While the economic output of the capital (Budapest) and of the regions of Western Transdanubia is higher than the average, the regions in the Eastern part of the country have lower output than the national average (Figure 1).

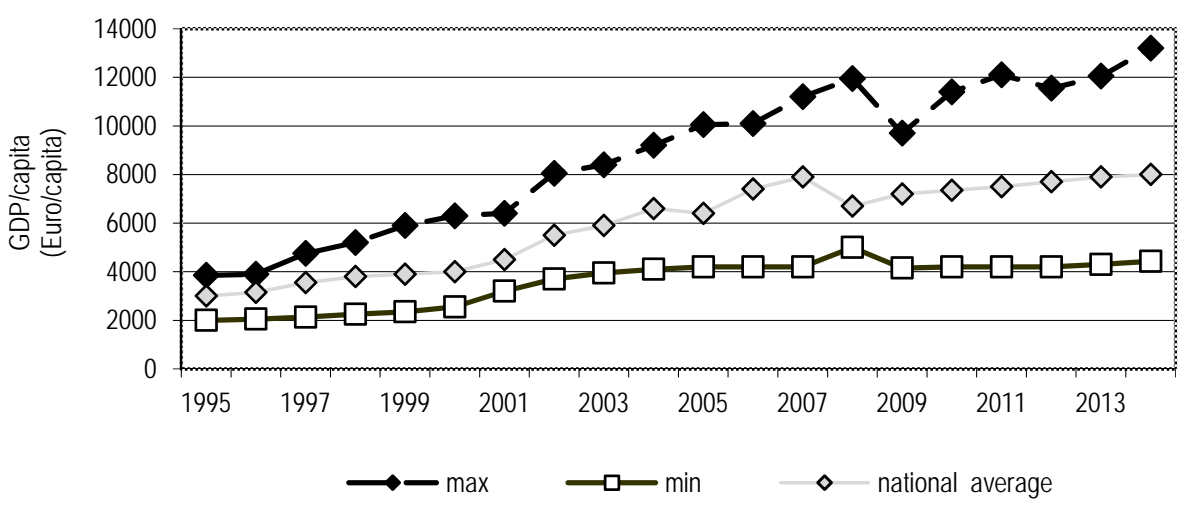

Figure 1 - Spatial disparities of economic output (authors own compilation based on dates of the Hungarian Central Statistics Office)

There are similar spatial differences in the case of the per capita R\&D\&I expenditures and the R\&D employment (Figure 2).

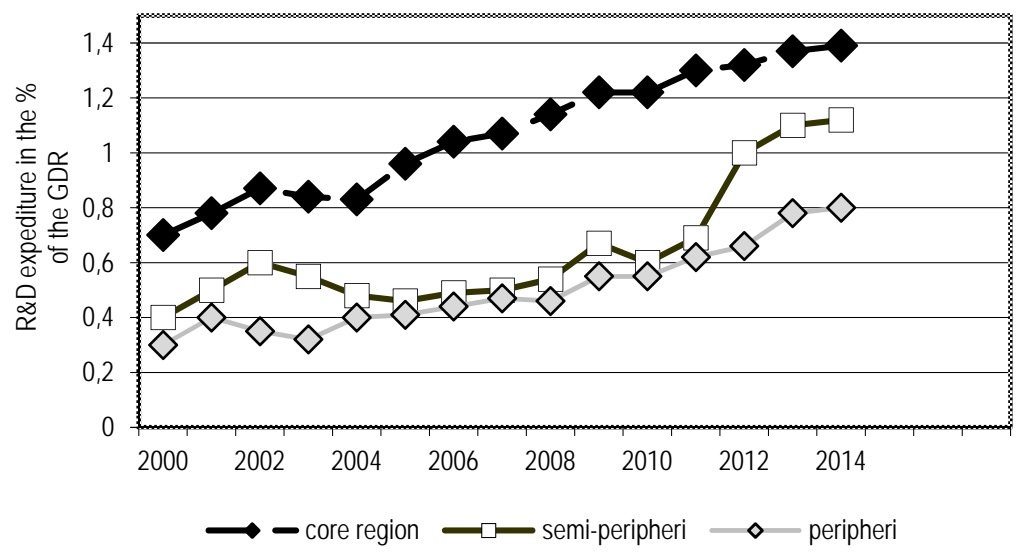

Figure 2 - R\&D expenditures in Hungary (2000-2014) (own calculation) 
Д. Коціскі, М. Верешне Шомоші. Підтримка створення та впровадження регіональних соціальних інновацій на основі інженерної системи знань

The main goal of our almost two decades long research: generating activities which can help the economic growth and social development of the settlements and regions in peripheral situation; creating resources for the implementation of ideas; monitoring of changes; and avoiding factors which hinder the sustainability [16].

To achieve these goals the Faculty of Economics at the University of Miskolc has created a Social Innovation Competence Centre in 2015, whose basic functions are as follows:

a) elaborating local economic development and social innovation supporting programs in the peripheral regions,

b) guidance in connection with these programs, and

c) creating a special training portfolio which helps social innovation, and generating educational programs.

The above mentioned three goals are equivalent, but as our experience shows the generation of sustainable innovative programs which are adequate for local problems and capabilities has a higher priority.

To find consistent solutions there is a need for consistent database, methodological and financial knowledge. The knowledge engineering system presented in this research is a supporting tool of these. The structure of social innovation knowledge engineering system.

The researchers have elaborated a lot of knowledge engineering (knowledge based) systems (for example: DENDRAL, MYCIN, EMYCIN, JESS, etc.) in the last thirty years. Most of these support a solution for natural sciences problems (like medical, Nano techno- logical, etc.), in the field of social sciences there were fewer systems found.

The well-known knowledge engineering systems differ in several characters (for example, user interface, knowledge representation method, technological characteristics, labour intensity, etc.).

Our own formalized social innovation knowledge engineering system has got six main parts (Figure 3).

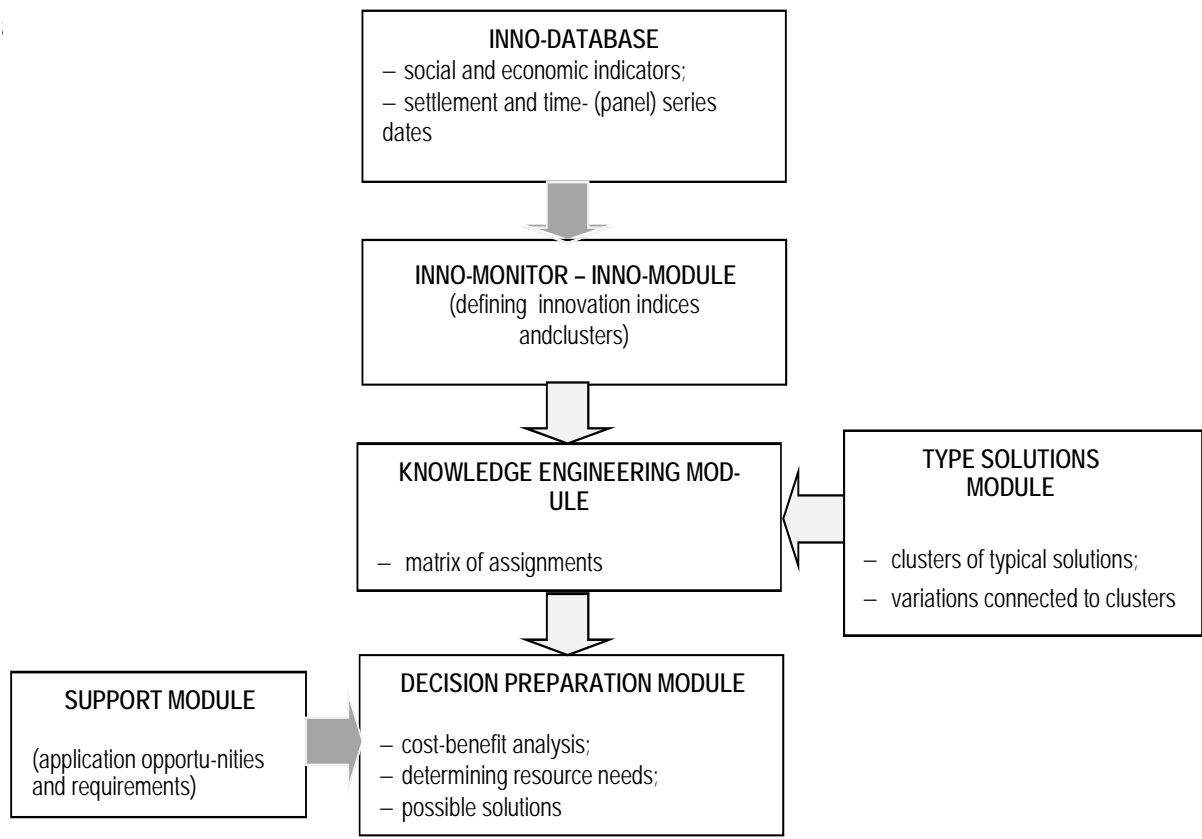

Figure 3 - The structure of social innovation knowledge engineering system (own compilation) 
- database, which contributes to the time and settlement-series accessibility of indicators determining the local innovation potential,

- monitoring module, which helps to determine the vertical and horizontal causalities,

- module of type solutions,

- supporting module, which outlines the national and foreign resources available for implementation,

- artificial intelligence module, and decision preparation module, which can help by formulating social innovation recommendations.

User side characteristics of our knowledge engineering system:

- regulated operation (problem solving), it depends on the database and the mechanism operating parallelly with the database; the system gives recommendations for problem solving;

- it is easy to operate, the role of user appears first in the decision preparation module.

Beside the general data, our database also contains R\&D\&I and social innovation data for 1600 Hungarian settlements (58\% of the Hungarian settlements) for the 1995-2014 time period (the upload and maintenance of the data will be done once a year). The data source is the Hungarian Central Statistics Office (Table 1).

Table 1 - Structure of Inno-database (own compilation)

\begin{tabular}{|c|c|}
\hline \multicolumn{2}{|c|}{ General dates (settlement and time-series) } \\
\hline $\begin{array}{l}\text { - population; } \\
\text { - demographic distribution; } \\
\text { - income dispersion }\end{array}$ & $\begin{array}{l}\text { - density of enterprises; } \\
\text { - activity rate; } \\
\text { - employment rate; } \\
\text { - unemployment rate }\end{array}$ \\
\hline R\&D\&I input indicators & Social input indicators \\
\hline $\begin{array}{l}\text { Organizational background } \\
\text { - number of R\&D\&l places; } \\
\text { - size of R\&D\&I expenditures; } \\
\text { - number of R\&D projects; } \\
\text { - application requirements }\end{array}$ & $\begin{array}{l}\text { Organizational background } \\
\text { - number of NGOs; } \\
\text { - number of non-profit enterprises; } \\
\text { - employees in non-profit enterprises; } \\
\text { - available support resources; } \\
\text { - application requirements }\end{array}$ \\
\hline $\begin{array}{l}\text { Location factors } \\
\text { - support requirements; } \\
\text { - R\&D\&I infrastructure (e.g. higher education institute, } \\
\text { research institute, etc.) }\end{array}$ & $\begin{array}{l}\text { Location factors } \\
\text { - support requirements; } \\
\text { - social infrastructure (e.g. social organizations, etc.) }\end{array}$ \\
\hline $\begin{array}{l}\text { Human requirements } \\
\text { - share of people with higher education degree in the } \\
\text { population; } \\
\text { - innovation age-quotient }\end{array}$ & $\begin{array}{l}\text { Human requirements } \\
\text { - share of active-aged population without a profession }\end{array}$ \\
\hline
\end{tabular}

The data management solution is based on SQL type, because of its simplicity and Windows compatibility [16].

The social innovation potential of a given settlement can be defined on the basis of 20 factors. Because of the heterogeneity of the indicators we have grouped the 1600 settlements into clusters (Figure 4).

As a result of the analysis we have created five clusters: to the first (lowest) group belong $27 \%$ of the examined settlements, to the second (low) $31 \%$, to the third (average) $18 \%$, to the fourth (high) $14 \%$, and to the fifth (outstanding) the 10\% of the settlements. 
Д. Коціскі, М. Верешне Шомоші. Підтримка створення та впровадження регіональних соціальних інновацій на основі інженерної системи знань

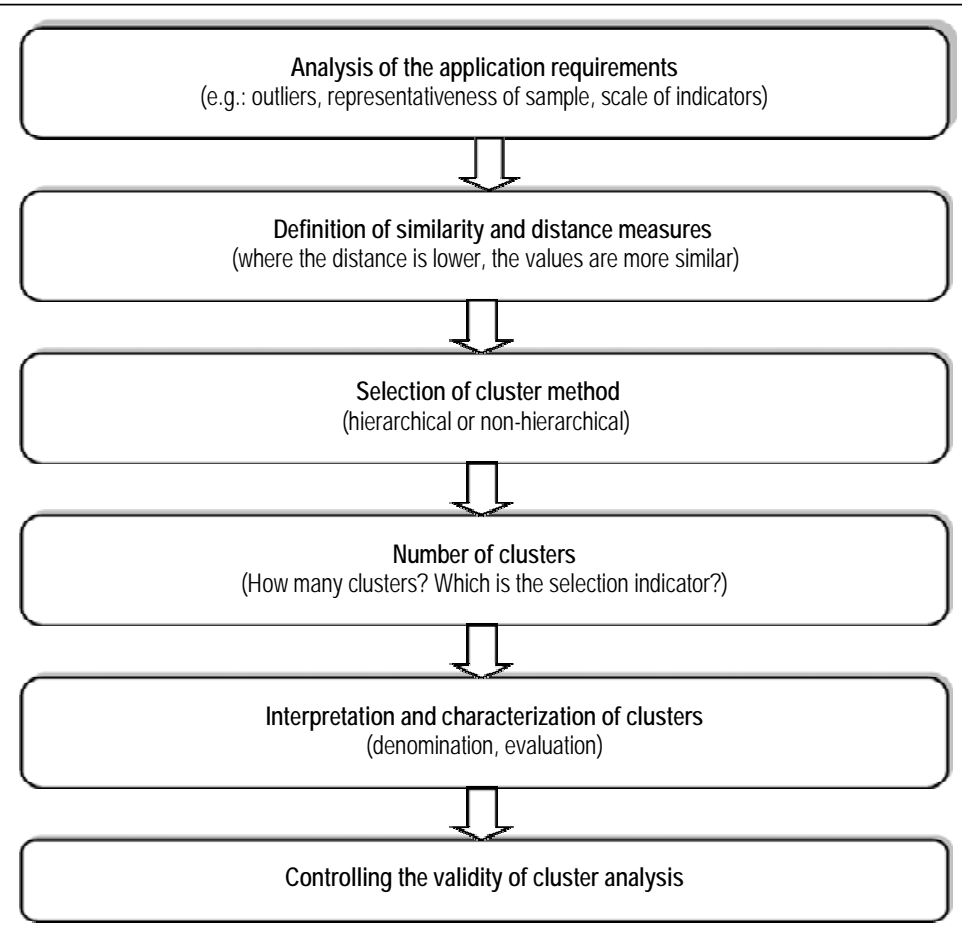

Figure 4 - Logical process of the cluster analysis (own compilation)

The module gives type solutions based on nine components (innovation potential, available support forms, solution levels, qualification needs, investment needs, qualification supply, labour force needs, and location needs).

There are several definitions of social innovation. Some of these give the opportunity of wider, while others provide narrower implementation [8; 19].

The definition of Gillward is the closest to our standpoint, which defines the social innovation as "an initiative of a given community to change its own situation" [14, p.1].

The emphasis should be put on the willingness to change the situation, and on the other hand on locally new or recent solutions. For the community it is important to find a solution consciously, hence recommendations based on the local capabilities and coming from outside have smaller chances to adapt and sustain due to the lack of adaptation willingness.

The creation of the type solutions' catalogue (module) has started on the one hand because of maintaining motivation and on the other hand to secure professionalism. Until now we have created five main groups (improving employment, increasing value added, improving health care and social situation, improving infrastructure, settlement development), to which wehave defined type solutions. In the type solutions module the framework of solutions is based on live work, location, investment and qualification needs. The assignment to goals is made according the typology of possible innovations (Figure 5).

The main aims of innovation can be found in the rows of the first (goal - innovation) matrix, while in the columns one can see the type solutions (social innovations) collected for solving the problem (the aim is to define the assignment with an X). To fulfill this aim the second matrix (characteristic innovation) gives help, there are the parameters characterizing the type solutions in its rows, while the columns are the same as the columns of the goal - innovation matrix. 


\section{Розділ 3 Інноваційний менеджмент}

\begin{tabular}{|c|c|c|c|c|c|c|c|c|c|c|c|}
\hline \multirow{2}{*}{ Goals } & \multicolumn{5}{|c|}{ Innovation types } & \multirow{2}{*}{ Goals } & \multicolumn{5}{|c|}{ Characteristic } \\
\hline & $\mathrm{N}$ & $\ldots$ & $\mathrm{N}$ & $\ldots$ & № & & $\mathrm{N}$ & $\ldots$ & $\mathrm{N}_{1}$ & $\ldots$ & $\mathrm{N}_{1}$ \\
\hline $\mathrm{G}_{1}$ & $X$ & & & & & $\mathrm{G}_{1}$ & & & & & \\
\hline$\cdots$ & & & & & & $\cdots$ & & & & & \\
\hline$G_{1}$ & $X$ & & $X$ & & & $G_{1}$ & & & & & \\
\hline$\cdots$ & & & & & & $\cdots$ & & & & & \\
\hline $\mathrm{G}_{1}$ & $X$ & & & & X & $G_{1}$ & & & & & \\
\hline
\end{tabular}

Figure 5 - Matrices created by the selection of social innovation (compiled by the authors)

Social innovations can be ranked by different characteristics and parameters, and in this way we can get the characteristic - innovation matrix. The connection between the aims and characteristics can be also defined. We formulate regulations to the realization of some aims (based on the characteristic innovation matrix), and as a result of it we get the assignments of the goal - innovation matrix (Table 2 shows an example for this).

Table 2 - Assignment example (compiled by the authors)

\begin{tabular}{|c|c|c|}
\hline \multicolumn{3}{|r|}{ Social innovations } \\
\hline ai & form & function \\
\hline \multirow[b]{2}{*}{$\begin{array}{l}\text { 1. Improving } \\
\text { employment }\end{array}$} & - settlements' economy & - employment of low qualified persons \\
\hline & $\begin{array}{l}\text { - settlement development/ } \\
\text { urban development }\end{array}$ & - driving back to the world of work, professional training \\
\hline \multirow{4}{*}{$\begin{array}{l}\text { 2. Increasing value } \\
\text { added }\end{array}$} & $\begin{array}{l}\text { - social agricultural } \\
\text { employment }\end{array}$ & $\begin{array}{l}\text { - production of bio products; } \\
\text { - production of biomass; } \\
\text { - production of craft products; } \\
\text { - collecting and growing herbs }\end{array}$ \\
\hline & - social farm & - livestock breeding \\
\hline & - social start-up & - processing herbs \\
\hline & - social cooperative & - production/ sale \\
\hline \multirow{4}{*}{$\begin{array}{l}\text { 3. Improving } \\
\text { health care and } \\
\text { social situation }\end{array}$} & $\begin{array}{l}\text { - support for periodical home } \\
\text { care }\end{array}$ & $\begin{array}{l}\text { - there are several cases (e.g. if a person needs medical care or } \\
\text { attendance be- cause of disease, akinesia, fracture, and a family } \\
\text { member or an adherent takes care of him with the help of adequate } \\
\text { services) }\end{array}$ \\
\hline & - 24 hours home service & - care for persons living alone (also the persons in mental illnesses) \\
\hline & $\begin{array}{l}\text { - care in boarding home for } \\
\text { elderly people }\end{array}$ & - securing 24 hours long supervision \\
\hline & - making social kitchen & - securing public catering \\
\hline
\end{tabular}



основі інженерної системи знань

The selection of type innovations can be made through the following four steps:

1. The user gets questions along the program, which ask about the evaluation characteristics!

2. The user defines its needs per characteristics because of the differentiated perception.

3. The knowledge engineering system contains the answers as basic data.

4. The answers given to several evaluation characteristics aggregately make the given innovations probable for application.

The knowledge engineering module, as the above mentioned prove it, gives recommendations for the solution. The objective of the expert(s) is to describe the final suggestion/recommendation (Figure 6).

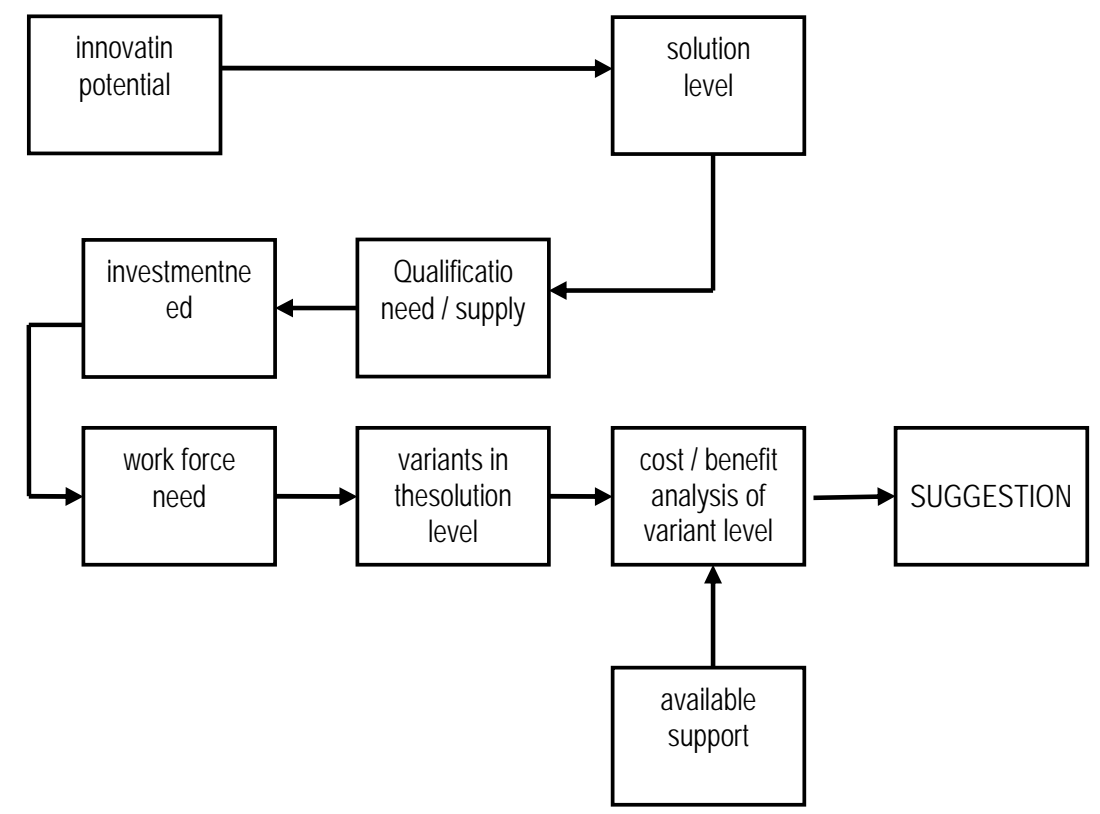

Figure 6 - Logical frame of the odule (compiled by the authors)

In the process the expert should answer several questions. The authors recommend that these issues include the following:

1. Modernity level of the products and services created by the examined organization?

2. The relation of the current activity to the former activities of the organization?

3. The competitiveness of the products and services?

4. Character of the production and service structure?

5. Modification types of the organization's product and service structure?

6. Advantages and disadvantages of the organization's products connected to social innovation?

7. Aims and target groups of the social innovation products and services?

8. Main characteristics of the social innovation products and services?

9. Competition threatening the organization's social innovation activity?

10. New development trends in the organization in connection with social innovation?

11. Weaknesses and type errors of the social innovation's process?

12. Expected share of social innovation in the revenue?

13. Degrees of novelty in the social innovation?

14. Content sources of the social innovation products and services?

15. Financial resources of the social innovation products and services? 
16. Resource and expenditure share of social innovation?

17. The adequacy of the organization for social innovation activities?

18. Relevant factors in connection with social innovation?

19. Obstacles in connection with social innovation process?

20. Sources of required information for social innovation?

21. Cooperation through the social innovation?

22. To the social innovation involved external organizations and actors?

23. Participants of the implementation of social innovation?

24. Role of the organization in the knowledge transfer actions?

To answer these there is a need for involving local specialists.

Conclusions and perspectives for further researches. The article presents scientific and methodical basesfunctioning of the engineering knowledge base to create a Bank of social innovations in the regions of Hungary. The authors were tested by in 2015-2016. As a result of these actions was sdelany the following conclusions:

- the biggest obstacle to social innovation is not lack of resources, and the lack of ideas and desires of the local and Central authorities;

- for social issues, development and implementation of social innovations are encouraged, first, substantially to raise the role and importance of local and regional government, activity and commitment to increasing local innovation capacity, and second, to increase the economic feasibility of management decisions in the field of social innovation;

- social innovation is encouraged to consider differentially that will lead to greater efficiency in their implementation, since a comprehensive solution will require significant investment and time.

Prospects for further research on this topic should refer to the formation of methodological approaches to the identification of needs in social innovation. The authors suggest the extension of these studies to other countries, as well as consideration in terms of social innovation projects for the industry.

1. Autio, E. (1998). Evaluation of RTD in Regional Systems of Innovation. European Planning Studies, Vol. 6, 2, 131-140 [in English].

2. Bund, E. et.al. (2013). Report on Innovation Metrics. Capturing Theoretical, Conceptual and Operational Insights for the Measurement of Social Innovation. University of Heidel- berg, Centre for Social Investment [in English].

3. Clar, G., Corkapis, D., \& Landabaso, M. (2001). Mobilizing Regional Foresight Actors to Strengthen the Strategic Basis of the European Research Area. IPTS Report, 59, 38-45 [in English].

4. Cook, P., \& di Marchi, B. (2002). Generative Growth, Knowledge Economies und Sustainable Development: Implications for Regional Foresight Policy. EC STRATA ETAN Working Group Papers [in English].

5. EC. (1995). Green Paper on Innovation. European Commission, Brussels. 1995. December. EC (1996). Assessment of the Regional Innovation Support Infrastructure. Methodology in Design, Construction and Operation of Regional Technology Frameworks. Volume I. EIMS Publication No. 19, DG XIII. Brussels [in English].

6. EC. (2001). Commission Staff Working Paper. 2001 Innovation Scoreboard (SEC-2001-1414). Brussels, 2001. 09. 14 [in English].

7. EC. (2002). EUs innovation performance still needs improvement, but there are encouraging signs for the future. Brussels, December 16 [in English].

8. EC. (2014). Strengthening social innovation in Europe [in English].

9. European Commission. (1992). Towards a Europe of solidarity. Intensifying the struggle against social exclusion, furthering social integration. COM (92) 542 [in English].

10. European Commission. (1993). The Future of European Social Policy: Options for the Union. A Green Paper. COM (93) 551 [in English].

11. European Commission. (2005). Communication from the Commission on the Social Agenda. COM (2005) 33 [in English].

12. FOREN. (2001). A Practical Guide to Regional Foresight, Foresight for Regional Development Network, Brussels: European Commission, Research Directorate General, Strata Programme [in English].

13. Frascati Manual. (1963). OECD, Paris [in English].

14. Gillwald, K. (2000). Konzepte Soziale Innovation. WZB, Berlin [in German].

15. Howaldt, J., \& Schwarz, M. (2010). Soziale Innovation im Fokus. Skizze eines gesellschafts-theoretisch inspirierten Forschungskonzepts. Transcript Verlag, Bielefeld [in German]. 
Д. Коціскі, М. Верешне Шомоші. Підтримка створення та впровадження регіональних соціальних інновацій на основі інженерної системи знань

16. Kocziszky, Gy. (2010). Innomonitor - Regional innovation monitoring and forecasting system. BAROSS-EM07-EM-OMFB research project final report, Miskolc [in English].

17. Moulaert. (2013). The international Handbook Social innovation: collective action, social learning and transdisciplinary research. Cheltenham, Northampton [in English].

18. OECD. (1994). FRASCATI MANUAL: Proposed Standard practice for Surveys of Research and Experimental Development. Paris [in English].

19. Zapf, W. (1989). Über soziale Innovationen. Soziale Welt, 40. H. 1-2. p. 170-183 [in German].

20. Pererva, P.G., Kocziszky, G., Szakaly, D., \& Somosi Veres, M. (2012). Technology transfer. Kharkiv-Miskolc: NTU "KhPI" [in English].

Д. Коціскі, д-р екон. наук, професор, директор інституту регіональної економіки, Мішкольцський університет (м. Мішкольц, Угорщина);

M. Верешне Шомоші, д-р екон. наук, професор, декан економічного факультету, Мішкольцський університет (м. Мішкольц, Угорщина)

Підтримка створення та впровадження регіональних соціальних інновацій на основі інженерної системи знань

Проведені авторами дослідження дозволяють зробити висновок про те, що традииійна спрямованість інноваційної діяльності (банківська діяльність, промислове виробництво, реформа управління і т. п.) далеко не завжди з однаковою ефрективністю сприймаються в різних регіонах країни. В окремих регіонах иі інновації не призводять до соціальних поліпшень, що є передумовою необхідності генерування та впровадження окремого блоку соціальних інновацій. У статті обгрунтовано необхідність проведення соціальних інновацій. На прикладі функиіонування Центру соціальних інновацій міста Мішкольца вперше розроблений науково-методичний підхід до їх здійснення. Як основні структурні блоки цього підходу авторами пропонуються такі: а) визначення взаємозв'язку місцевого економічного розвитку та соціальних інновацій; б) формування ключових напрямків соціального поліпшення регіону (підвищення зайнятості, збільшення доданої вартості, поліпшення охорони здоров'я і соціального положення, поліпшення інфраструктури розвитку населеного пункту); в) розроблення програми соиіальних інновацій на основі регіональної системи інженерних знань; г) відбір ключових соціальних інновацій на основі запропонованої авторами інноваційної матриці і спеціальної методики; д) розроблення програми практичної реалізації інновацій соціальної спрямованості. Науково-методичні рекомендаиії, запропоновані в статmі, апробовані авторами впродовж останніх двох років. У результаті зроблений узагальнюючий висновок про те, що найбільшою перешкодою на шляху соціальних інновацій є не відсутність ресурсів, а відсутність ідей і бажання у місцевої і центральної управлінської еліти.

Ключові слова: інноваційна діяльність, регіони, соціальні інновації, інноваційний потенціал, генерування знань, інноваційна матриця.

Д. Коциски, д-р экон. наук, профессор, директор института региональной экономики, Мишкольцский университет (г. Мишкольц, Венгрия);

M. Верешне Шомоши, д-р экон. наук, профессор, декан экономического факультета, Мишкольцский университет (г. Мишкольц, Венгрия)

Поддержка создания и внедрения региональных социальных инноваций на основе инженерной системы знаний

Проведенные авторами исследования позволяют сделать вывод о том, что традиционная направленность инновационной деятельности (банковская деятельность, промышленное производство, реформа управления и т. п.) далеко не всегда с одинаковой эфффективностью воспринимаются в различных регионах страны. В отдельных регионах эти инновации не приводят к соииальным улучшениям, что является предпосылкой необходимости генерирования и внедрения отдельного блока социальных инноваций. В статье обоснована необходимость проведения социальных инноваций. На примере функционирования Центра социальных инноваций города Мишкольца впервые разработан научно-методический подход к их осуществлению. В качестве основных структурных блоков этого подхода авторами предлагаются следующие: а) определение взаимосвязи местного экономического развития и социальных инноваций; б) формирование ключевых направлений социального улучшения региона (повышение занятости, увеличение добавленной стоимости, улучшение здравоохранения и социального положения, улучшение инфрраструктуры развития населенного пункта); в) разработка программы социальных инноваций на основе региональной системы инженерных знаний; г) отбор ключевых социальных инноваций на основе предложенной авторами инновационной матрицы и специальной методики; д) разработка программы практической реализации инноваций социальной направленности. Научно-методические рекомендации, предложенные в статье, апробировань авторами в течение последних двух лет. В результате сделан обобщающий вывод о том, что самым большим препятствием на пути социальных инноваций является не отсутствие ресурсов, а отсутствие идей и желания у местной и центральной управленческой элиты.

Ключевые слова: инновационная деятельность, регионы, социальные инновации, инновационный потенциал, генерирование знаний, инновационная матрица.

Отримано 11112016p. 